\title{
Desain E-Module Tematik Berbasis Kesantunan Berbahasa Anak Usia Dini di Taman Kanak-Kanak
}

\author{
Sri Yunimar Ningsih ${ }^{1 凶}$, Nenny Mahyuddin² \\ Pendidikan Anak Usia Dini, Universitas Negeri Padang(1,2) \\ DOI: $10.31004 /$ obsesi.v6i1.1217
}

\begin{abstract}
Abstrak
Penelitian ini dilatarbelakangi oleh kondisi pandemik dan kemajuan teknologi yang berkembang pesat di era rovolusi 4.0 yang menuntut pendidik memiliki kemampuan beradaptasi dengan teknologi baru dan tantangan global. Penelitian ini bertujuan untuk menghasilkan e-module tematik berbasis kesantunan berbahasa anak usia dini di taman kanak-kanak yang valid, praktis dan efektif. Jenis penelitian ini adalah Research and Development (R\&D) menggunakan model ADDIE. Teknik analisis data menggunakan analisis statistik deskriptif dengan validasi Aiken'ns V. Hasil uji validasi materi e-module oleh ahli materi dan oleh ahli media dinyatakan valid dan layak digunakan. Hasil uji praktikalitas emodule dinyatakan praktis. Hasil persentase efektifitas e-module dinyatakan efektif. Dapat disimpulkan desain e-module tematik berbasis kesantunan berbahasa anak usia dini di taman kanak-kanak dinyatakan valid, praktis dan efektif.
\end{abstract}

Kata Kunci: e-module; tematik; kesantunan berbahasa; anak usia dini

\begin{abstract}
This research based on pandemic conditions and technological advances that are rapidly developing in the revolutionary 4.0 era, which demand teacher to have the ability to adapt to new technology and global challenges. This study aims to produce a thematic e-module based on politeness in kindergarten that is valid, practical and effective. This research use R\&D (Research and Development) Method using ADDIE model. The data analysis technique used descriptive statistical analysis with Aiken's V validation. The results of the e-module validation test by material experts and by media experts were declared valid and feasible used. The results of the e-module practicality test were declared practical. The result of the proportion of effectiveness was declared effective. Can be concluded that thematic e-module development based on child's language modesty in early childhood education stated valid, practical, and effective.
\end{abstract}

Keywords: e-modul; thematic; politeness; early childhood

Copyright (c) 2021 Sri Yunimar Ningsih, Nenny Mahyuddin

$\triangle$ Corresponding author:

Email Address: ningsihbening72@gmail.com (Padang, Indonesia)

Received 23 March 2021, Accepted 1 April 2021, Published 8 April 2021 


\section{PENDAHULUAN}

Kondisi pandemi covid 19 saat ini memberikan dampak yang begitu besar hampir pada semua sendi kehidupan, dunia pendidikan termasuk pendidikan anak usia dini. Hal ini menjadikan tuntutan terhadap guru PAUD akan melek teknologi menjadi kebutuhan yang mendesak. Karena selama masa pandemi penyelenggaraan kegiatan pembelajaran tidak lagi dapat sepenuhnya dilakukan secara tatap muka tetapi beralih pada kegiatan daring dan luring atau belajar jarak jauh (Pengelola Web Kemdikbud, 2020). Akibatnya terjadi perubahan yang sangat tiba-tiba dan tidak sedikit menimbulkan kekagetan budaya, baik bagi pendidik maupun peserta didik (Rizki Tiara \& Pratiwi, 2020)

Pembelajaran daring (dalam jaringan) dilakukan sebagai pilihan strategis dalam memutus mata rantai penyebaran wabah covid-19. Hal ini sesuai dengan Surat Edaran Menteri Pendidikan Nomor 3 Tahun 2020 pada Satuan Pendidikan dan Nomor 36962/MPK.A/HK/2020 tentang Pelaksanaan Pendidikan dalam Masa Darurat Coronavirus Disease (Pengelola Web Kemdikbud, 2020) Untuk daerah-daerah yang berada pada zona aman, pembelajaran tatap muka secara terbatas dapat dilakukan dengan menerapkan protokol kesehatan dan mengurangi interaksi langsung dengan orang lain.

Semua pihak mulai dari pendidik, orang tua dan peserta didik harus siap menjalani kehidupan baru (new normal) ini lewat pendekatan belajar menggunakan teknologi informasi dan media elektronik (Larson \& Miller, 2011). Dengan demikian kecepatan dan kemudahan dalam menyajikan informasi sebagai sumber belajar diperoleh dengan mudah (Triyono, 2015). Untuk itu pendidik PAUD perlu mempersiapkan media atau bahan ajar yang inovatif berbasis teknologi yang dapat digunakan dimana saja dan kapan saja. Baik pada pembelajaran daring, luring ataupun pembelajaran tatap muka. Modul elektronik atau e-module merupakan salah satu media atau bahan belajar yang mendukung pembelajaran menggunakan TIK (Zaharah \& Susilowati, 2020). E-module sangat fleksibel penggunaannya (dapat digunakan pada kegiatan tatap muka, daring maupun luring) dan sangat membantu pendidik dalam proses pembelajaran seperti kecepatan waktu penyajian materi, kemudahan penyajian dan meningkatkan motivasi belajar siswa karena didalamnya terdapat audio, visual dan animasi gerak yang manarik bagi anak usia dini (Sofyan et al., 2020). Anak usia dini lebih tertarik dan senang belajar jika menggunakan media pembelajaran yang bersifat interaktif. Anak juga menginginkan media pembelajaran yang penyajiannya dilengkapi gambar, video, musik dan animasi (Mahyuddin et al., 2018). Dengan demikian anak usia dini tetap mendapatkan stimulasi yang tepat selama masa pandemi ini terhadap pertumbuhan dan perkembangannya.

Pertumbuhan dan perkembangan anak usia dini perlu diarahkan pada peletakan dasar-dasar yang tepat bagi pertumbuhan dan perkembangannya yaitu pertumbuhan dan perkembangan fisik, daya pikir, daya cipta, sosial emosional, bahasa dan komunikasi yang seimbang sebagai dasar pembentukan pribadi yang utuh (Suryana, 2016). Aspek bahasa sebagai salah satu dari kemampuan dasar yang harus dimiliki anak. Dengan bahasa anak dapat mengkomunikasikan keinginannya dengan orang lain. Selain sebagai alat komunikasi bahasa juga dimaknai sebagai cerminan karakter seseorang (Kurniadi et al., 2017). Orang yang memiliki karakter baik biasanya menggunakan bahasa dengan santun. Sebaliknya, orang yang berkomunikasi tanpa mengindahkan kesantunan cenderung memiliki karakter yang kurang baik. Untuk itulah kesantunan berbahasa perlu ditanamkan pada anak sejak dini. Sejalan dengan hasil penelitian (Burdelski, 2010) terhadap anak usia dua sampai lima tahun di Jepang yang berjudul "Socializing Politeness Routines: Action, Other-orientation, and Embodiment in a Japanese Preschool, mengungkapkan pentingnya penanaman kesantunan berbahasa sehari-hari bagi anak usia dini karena hal ini merupakan wujud interaksi sosial sebagai sarana untuk menunjukkan kebaikan, empati, dan perilaku berorientasi lainnya yang merupakan tujuan utama dari pendidikan prasekolah.

Kesantunan berbahasa adalah sikap yang ditandai dengan perilaku berbahasa yang lemah lembut, sikap kerendahan hati, tenang dan penuh rasa hormat, (Kurniadi et al., 2017) Kesantunan berbahasa perlu ditanamkan pada anak sejak dini ketika anak-anak mulai belajar 
mengatualisasikan diri dengan lingkungannya. Dengan kesantunan berbahasa akan terbangun hubungan sosial yang baik dengan orang lain. Fenomena dilapangan kesantunan berbahasa anak usia dini masih rendah (Mahyuddin, M.Pd \& Rozimela, Ph, d, 2019) terlihat pada interaksi keseharian anak baik disekolah maupun dirumah sebagai dampak dari lingkungan yang kurang santun dan dampak pandemi yang menyebabkan dibatasinya interaksi sosial anak baik dengan guru, teman sebaya dan lingkungan sosial lainnya, (Suhendro, 2020). Untuk itu guru PAUD perlu mendesain pembelajaran dengan baik, menentukan metode dan media serta menyiapkan bahan ajar yang tepat sehingga pada situasi apapun anak usia dini sebagai investasi masa depan bangsa tetap mendapatkan stimulasi yang baik terhadap semua aspek perkembangan anak. Dengan demikian diharapkan bahan ajar yang dikembangkan berupa e-module tematik berbasis kesantunan berbahasa dapat digunakan guru PAUD sebagai salah satu sumber mengajar yang membantu guru dalam proses pembelajaran dan pemilihan strategi pembelajaran yang tepat dalam menanamkan kesantunan berbahasa pada anak usia dini di taman kanak-kanak. Karena e-module yang dikembangkan pada penelitian ini berbasis kesantunan berbahasa anak usia dini dikemas secara tematik, dilengkapi petunjuk pembiasaan pada anak yang diintegrasikan dengan proses pembelajaran.

Desain merupakan prosedur yang menjadi dasar pembuatan suatu produk sesuai dengan tujuan yang diinginkan. Desain berperan mengkomunikasikan informasi kepada pembaca dengan berbagai kekuatan visual seperti topografi, ilustrasi, warna, garis, tata letak dan lain sebagainya dengan bantuan teknologi, (Supriatna \& Mulyadi, 2009). Dengan demikian penggunaan desain dalam pembelajaran dapat membantu guru atau pendidik memberikan informasi kepada siswa atau peserta didik secara tepat dan menarik.

Modul adalah suatu proses pembelajaran mengenai satuan bahasan tertentu yang disusun secara sistematis, operasional dan terarah untuk digunakan oleh peserta didik, disertai dengan pedoman penggunaan untuk para pendidik. Modul pembelajaran sangat membantu dalam proses pembelajaran untuk membangkitkan keingintahuan, minat dan motivasi peserta didik. Media atau bahan ajar yang mendukung pembelajaran menggunakan TIK meliputi: audio, booklet, e-book, flipchart, game, leaflet, multimedia interaction (MMI), power point, mack-up, video, web best learning dan modul elektronik, (Ferdianto et al., 2019).

Penggunaan e-module pada masa pandemi selain dapat digunakan secara fleksibel (tatap muka, daring dan luring) juga sebagai pendayagunaan teknologi untuk optimalisasi pembelajaran anak usia dini di era global. Ini pembahasan penting yang perlu dipertimbangkan karena anak perlu diperkenalkan dengan produk teknologi agar anak dapat beradaptasi secara aman dan ketertarikan dalam mengembangkannya kelak (learnig to be) menjadi ahli dalam teknologi dalam bidang tertentu sesuai dengan bakat dan minatnya (Mahyurianti \& Mahyuddin, 2020)

Modul elektronik merupakan bentuk bahan ajar atau bahan belajar yang disusun secara sistematis yang ditampilkan dalam format elektronik, didalamnya terdapat audio, animasi dan navigasi. Aplikasi yang dapat digunakan untuk membuat e-module diantaranya exelearning, 3D Page Flip Professional; Flip PDF Professional (Ferdianto et al., 2019) dan Kvisoft Flipbook Maker, (Situmorang et al., 2020)

Aplikasi kvisoft flipbook maker merupakan salah satu aplikasi yang mendukung sebagai media pembelajaran yang akan membantu dalam proses pembelajaran. Aplikasi ini tidak terpaku hanya pada tulisan-tulisan saja tetapi bisa dimasukan sebuah animasi gerak, video, dan audio yang bisa menjadikan sebuah interaktif media pembelajaran yang menarik sehingga pembelajaran menjadi tidak monoton, (Wibowo \& Pratiwi, 2018). Penerapan teknologi interaktif dalam lingkungan pembelajaran mampu membangkitkan semangat peserta didik dalam proses pembelajaran (Ramadhan \& Linda, 2020) sehingga penggunaan emodule sangat membantu guru anak usia dini dalam kegiatan pembelajaran dan meningkatkan minat anak usia dini mengikuti kegiatan pembelajaran (Sofyan et al., 2020). 
Kurikulum 2013 Pendidikan Anak Usia Dini menggunakan pembelajaran tematik yang dimaknai sebagai pembelajaran yang dirancang berdasarkan tema-tema tertentu (Al-Tabany, 2013). Tema merupakan topik yang menjadi payung untuk mengintegrasikan seluruh konsep dan muatan pembelajaran melalui kegiatan main dalam mencapai kompetensi dan tingkat perkembangan yang diharapkan (Yuliastri \& Ramdhani, 2018)

Tabel 1. Kesantunan Berbahasa pada Kompetensi Inti dan Kompetensi Dasar Kurilukum 2013 PAUD

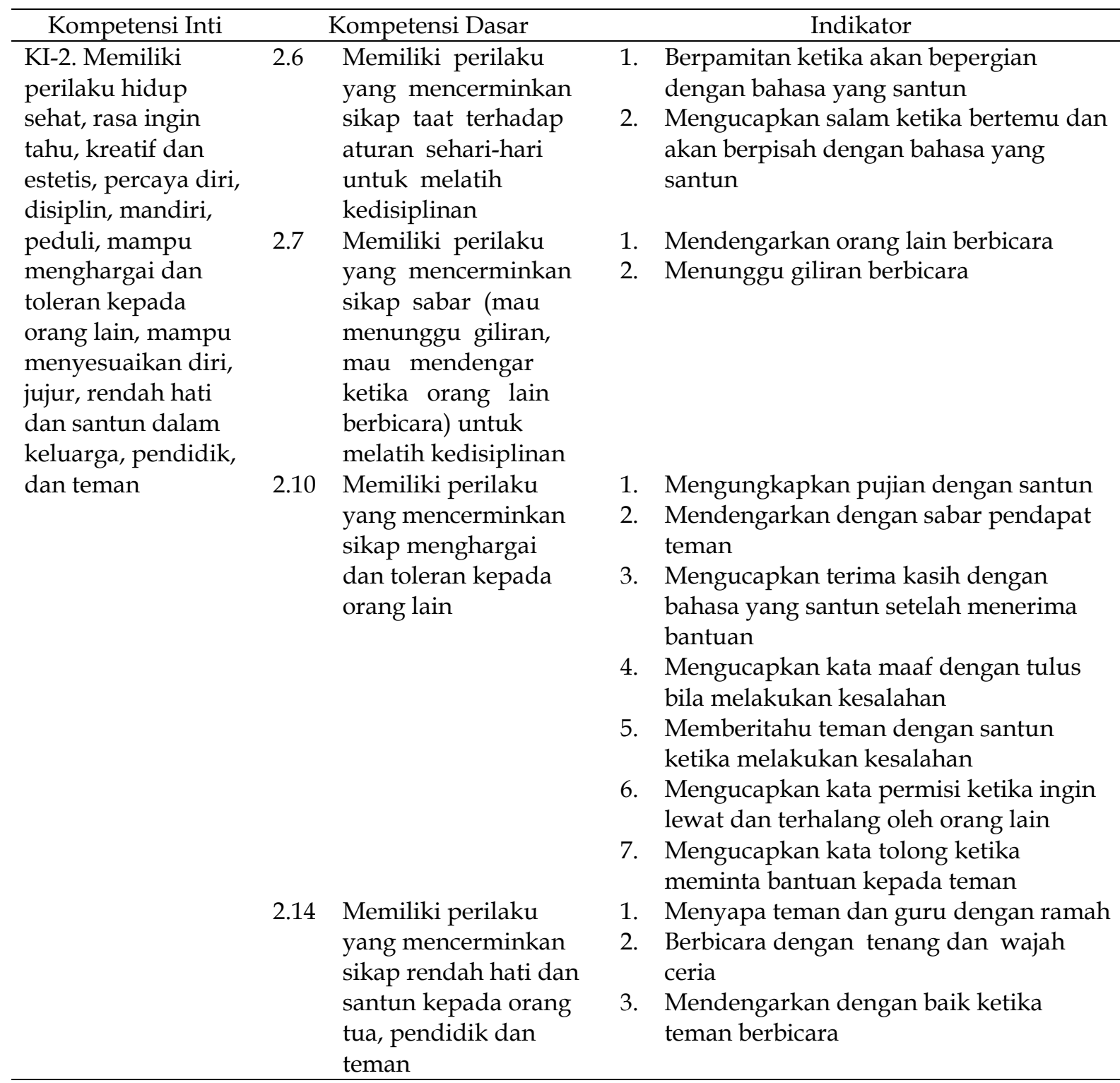

Sumber: Permendikbud 146 dan Penelope Brown \& Stephen C. Levinson

\section{Penanaman sikap Kesantunan Berbahasa Anak Usia Dini}

Penanaman sikap santun dalam berbahasa pada anak usia dini memiliki peran yang sangat penting dalam membangun karakter anak sejak dini. Sebagaimana hasil kajian dilakukan para peneliti linguistik dibeberapa Negara, diantaranya adalah; hasil penelitian (Burdelski, 2010) terhadap anak usia dua ampai lima tahun di Jepang yang berjudul "Socializing Politeness Routines: Action, Other-orientation, and Embodiment in a Japanese Preschool, mengungkapkan pentingnya penanaman kesantunan berbahasa sehari-hari bagi anak usia dini karena hal ini merupakan wujud interaksi sosial sebagai sarana untuk menunjukkan kebaikan, empati, dan perilaku berorientasi lainnya yang merupakan tujuan utama dari pendidikan prasekolah. Sejalan dengan penelitian (Zhang \& Yan, 2012) terhadap 
128 anak usia dini di Cina, menunjukkan bahwa tindak tutur atau kesantunan berbahasa merupakan variabel penting kedua yang mempengaruhi kompetensi sosiopragmatik bahasa awal anak. Dalam berbahasa terdapat kaidah yang harus dipatuhi karena berlaku sebagai aturan bagi suatu masyarakat tertentu.Terdapat kaidah kesantunan yang menjadi tolak ukur agar komunikasi yang dilaksanakan berjalan lancar.

Kesantunan berbahasa merupakan konsep tentang bagaimana cara berbahasa yang baik dan benar. Strategi kesantunan positif mengedepankan bagaimana kita sudah semestinya dan seharusnya menghormati orang lain. Sebaliknya, strategi kesantunan negatif lebih didasarkan pada bagaimana kita menghormati orang lain supaya orang lain itu menghargai kita (Prayitno, 2015). (Kurniadi et al., 2017)(Brown \& Levinson, 1988) dalam bukunya yang berjudul "Politeness Some Universal In Language Usage" memaparkan bahwa anak berusia 2,5 tahun mulai bisa mengucapkan kata tolong untuk meminta bantuan dalam memenuhi kebutuhannya. Pada usia 4 hingga 6 tahun anak mulai menggunakan beberapa derajat kesantunan dalam bermain atau berinteraksi seiring dengan semakin terbangunnya pemerolehan bahasa anak seperti mngucapkan terima kasih ketika memperoleh sesuatu, mengucapkan kata maaf setelah melakukan kesalahan, mengucapkan permisi ketika terhalang oleh orang lain serta mulai memperhatikan norma komunikatif dan gaya norma komunikatif dan gaya interaksional sesuai dengan budaya perlu ditanamkan pada anak.

Dalam struktur K-13 PAUD pengembangan kompetensi sikap meliputi kompetensi sikap spiritual dan sikap sosial. Kesantunan berbahasa termuat dalam kompetensi sikap sosial (Tabel 1.)

\section{METODOLOGI}

Penelitian ini adalah penelitian pengembangan (reseach and development) untuk menghasilkan suatu produk yaitu e-module tematik berbasis kesantunan berbahasa untuk anak usia dini. Dalam penelitian ini, model pengembangan yang digunakan adalah model ADDIE yang dilakukan dengan lima tahap, yaitu Analysis, Design, Development, Implementation, and Evaluation (ADDIE) yang dikemukakan oleh (Branch, 2019). Alasan peneliti menggunakan model ADDIE ini adalah tahapan pengembangannya dianggap lebih sederhana dibandingkan dengan pengembangan model lainnya, tahapan-tahapannya terstruktur secara sistematis dari tahap pertama sampai tahap kelima.

Pengembangan e-module tematik berbasis kesantunan berbahasa anak usia dini di taman kanak-kanak dilaksanakan di Taman Kanak-kanak Insan Kamil Dharmasraya. Prosedur pengembangan yang dilakukan sesuai dengan tahap-tahap model pengembangan ADDIE yang dikemukakan oleh (Branch, 2019) dengan lima fase tahapan sebagaimana yang terlihat pada gambar 1 .

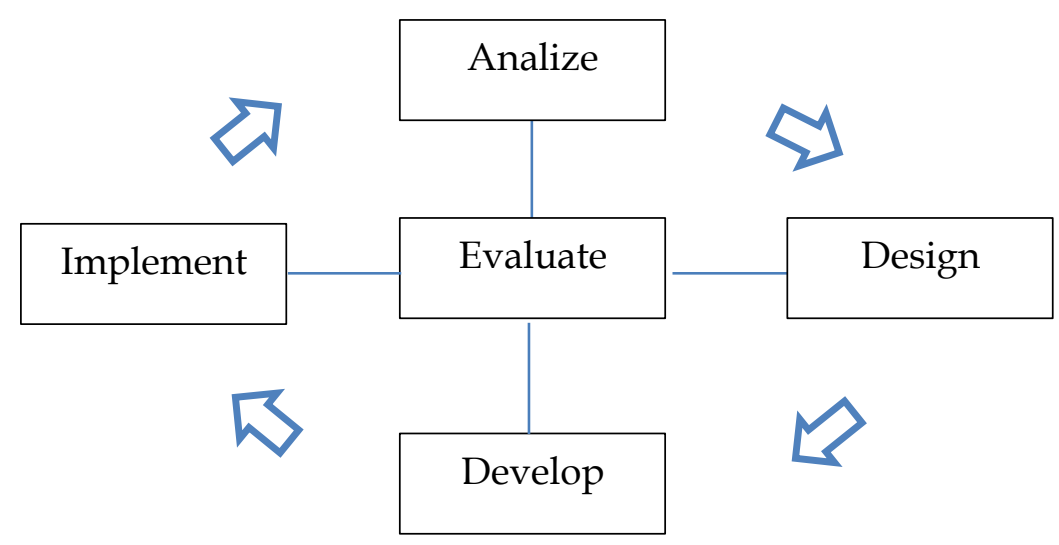

Gambar 1. Model ADDIE dan Tahapannya

Sumber: Branch, 2009 
Teknik pengumpulan data dalam penelitian ini adalah menggunakan berbagai instrumen. Adapun instrumen yang gunakan dalam pengembangan ini adalah instrumen validitas; desain e-module divalidasi oleh ahli terlebih dahulu untuk mengetahui ketepatan komponen penyusunannya. Instrumen yang digunakan adalah lembar validasi berupa angket. Angket disusun berdasarkan indikator meliputi kelayakan isi, penyajian, kebahasaan dan kegrafikaan dalam e-module. Instrumen selanjutnya adalah lembar kepraktisan digunakan untuk mengumpulkan informasi kepraktisan e-module yang dikembangkan. Instrumennya diisi oleh guru untuk mengetahui respon guru terhadap praktikalitas e-module. Sebelum digunakan dilapangan angket ini terlebih dahulu divalidasi oleh validator agar angket memiliki kevalidan yang tinggi. Selain instrument validitas dan praktikalitas juga dihgunakan instrument efektivitas, berupa angket yang digunakan untuk mendapatkan data yang diperlukan dalam menemukan persentase keberhasilan $e$-module tematik berbasis kesantunan berbahasa.

Teknik analisis data dari hasil penelitian dilakukan untuk mengetahui validitas dan praktikalitas e-module yang dibuat. Data hasil penelitian dianalisis menggunakan statistik deskriptif yaitu dengan mendeskripsikan tingkat validitas, praktikalitas dan efektivitas emodule.

\section{HASIL DAN PEMBAHASAN}

Penelitian dan pengembangan yang sudah dilakukan menghasilkan produk berupa Desain E-module Tematik Berbasis Kesantunan Berbahasa Anak Usia Dini di Taman Kanakkanak. Pengembangan desain e-module tematik ini menggunakan model ADDIE dengan 5 tahapan yaitu Analys, Design, Development, Implementation dan Evaluation. Hasil yang diperoleh sesuai tahap pengembangan yang dilakukan adalah:

\section{Analysis (Analisis)}

Analisis kebutuhan merupakan kegiatan menganalisis silabus atau kurikulum untuk memperoleh informasi modul yang dibutuhkan peserta didik dalam mempelajari kompetensi yang telah diprogramkan. Tahap ini merupakan tahap awal dari pengembangan yang dilakukan.

Tahap awal dalam menganalisis kebutuhan peneliti melakukan analisis terhadap kurikulum untuk memperoleh informasi modul yang dibutuhkan peserta didik dalam mempelajari kompetensi yang telah diprogramkan. Peneliti menggunakan metode observasi dan wawancara. Adapun hasil analisis yang diperoleh adalah sebagai berikut: pertama analisis kurikulum (KTSP); peneliti melakukan analisis terhadap kurikulum TK Insan Kamil yang meliputi dokumen I dan dokumen II. Program semester I TK Insan Kamil yang selanjutnya dituangkan pada rencana pembelajaran (RPPM) terdapat salah satu tema yaitu tema Akhlakul Karimah. Melalaui observasi peneliti mengumpulkan informasi tentang rencana pembelajaran tersebut yang nantinya akan digunakan pada e-module berdasarkan kompetensi dasar dan kompetensi inti yang diterapkan di TK Insan Kamil. Kedua peneliti melakukan analisis guru dan peserta didik; guru taman kanak-kanak TK Insan Kamil berjumlah tiga orang. Hasil analisis berdasarkan hasil wawancara dengan guru yaitu ibu Desra Mulya, S. Pd adalah kemampuan guru dalam membuat dan mengembangkan bahan ajar digital masih rendah sehingga bahan ajar digunakan selama ini berupa buku paket yang dijual di pasaran. Kegiatan pembelajaran menjadi menoton dan kurang menarik minat anak. Permasalahan lainnya adalah penanaman nilai-nilai kesantunan kepada anak juga dilakukan pada waktu tertentu saja dengan metode bercerita dengan menggunakan media buku cerita bergambar. Desain pembelajaran yang digunakan adalah pendekatan pembelajaran tematik.

Analisis peserta didik meliputi anak usia 4 sampai 6 tahun di Taman Kanak-kanak Insan Kamil yang berjumlah 20 anak. 10 anak kelas B1 dan 10 anak di kelas B2. Hasil observasi awal yang peneliti peroleh terhadap kesantunan berbahasa anak masih rendah belum memenuhi prinsip-prinsip kesantunan berbahasa anak usia dini. 
Berdasarkan hasil analisis ini, peneliti tertarik untuk mengembang e-module tematik berbasis kesantunan berbahasa untuk anak usia dini di Taman Kanak-kanak.

\section{Design (Desain)}

Berdasarkan analisis yang sudah dilakukan peneliti mulai membuat rancangan. Penulisan e-module dilakukan sesuai dengan RPP tematik dan mengintegrasikan nilai-nilai kesantunan berbahasa. Langkah-langkah yang peneliti lakukan pada tahap desain ini adalah menyusun kerangka e-module dan mendeskripsikan kerangka e-module.

Pada tahap Menyusun kerangka peneliti menetapkan kerangka bahan yang akan disusun, menetapkan tujuan akhir yang harus dicapai anak setelah selesai menggunakan emodule, menetapkan tujuan kemampuan spesifik yang menunjang tujuan akhir yaitu pembiasaan sikap santun dalam berbahasa. Selanjutnya pada tahap mendeskripsikan emodule peneliti menggunakan struktur atau kerangka yang sederhana sesuai dengan kebutuhan sebagaimana terlihat pada gambar 2 .

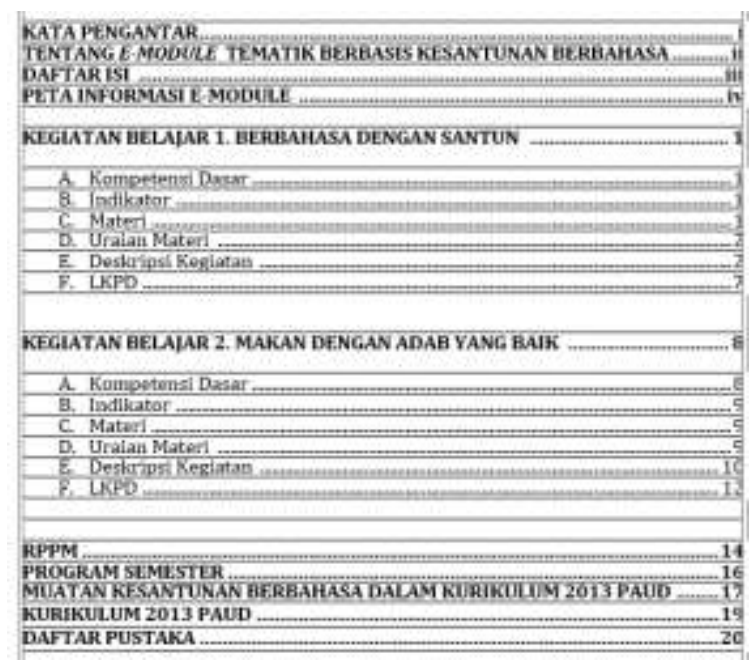

\section{Gambar2. Kerangka e-module}

Desain e-module ini dikembangkan secara tematik sesuai dengan desain pembelajaran anak usia dini. pembelajaran anak usia dini 4-6 tahun yang mengacu pada kurikulum 2013 PAUD yang diintegrasikan dengan nilai-nilai kesantunan berbahasa anak usia dini usia 5-6 tahun. Masing-masing materi pada sub tema terdapat video animasi sesuai dengan materi pembelajaran.

\section{Development (Pengembangan)}

E-module dikembangkan menggunakan software kvisoft flipbook maker untuk merubah draf (modul) menjadi e-module. Lembaran e-module di desain menggunakan aplikasi canva dengan tampilan sebagaimana pada gambar 3-13.

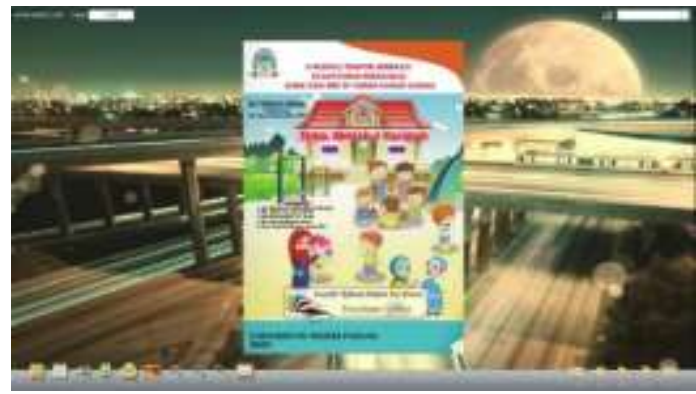

Gambar 3. Desain cover e-module

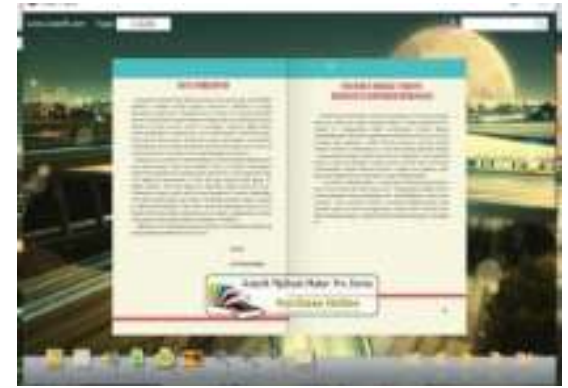

Gambar 4. Desain kata pengantar 


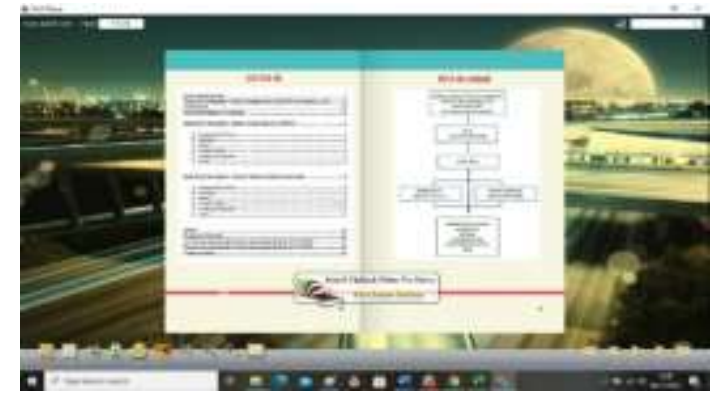

Gambar 5. Desain daftar isi dan peta informasi

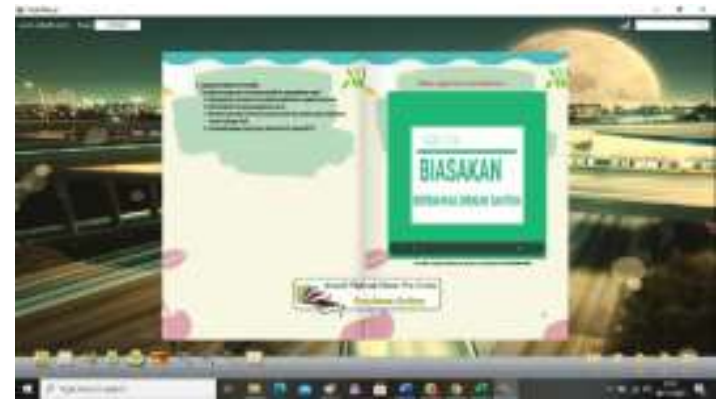

Gambar 7. Desain video pembelajaran

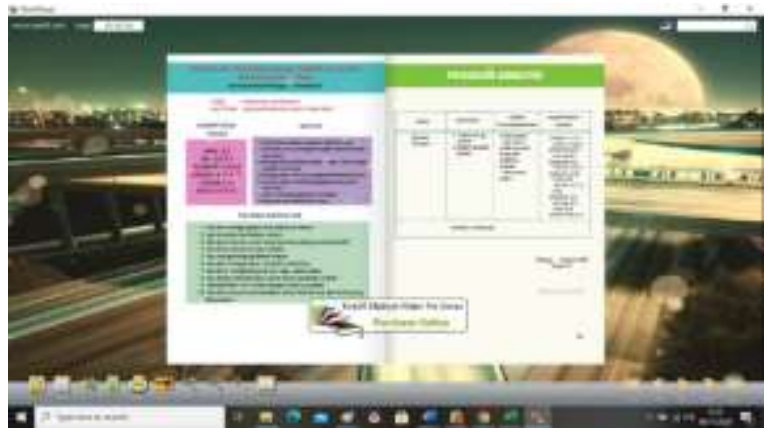

Gambar 9. Desain program semester

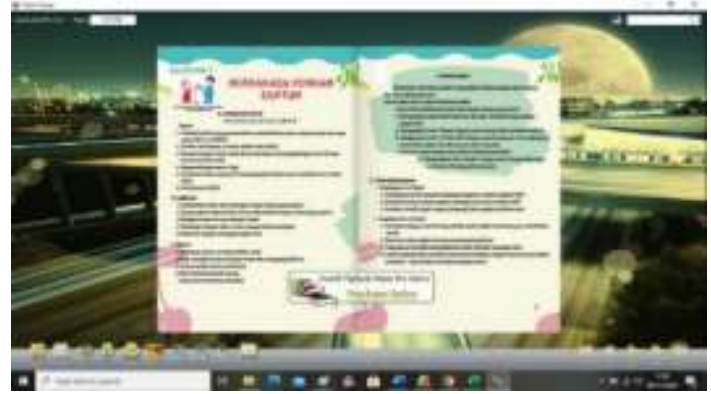

Gambar 6. Desain kegiatan pembelajaran

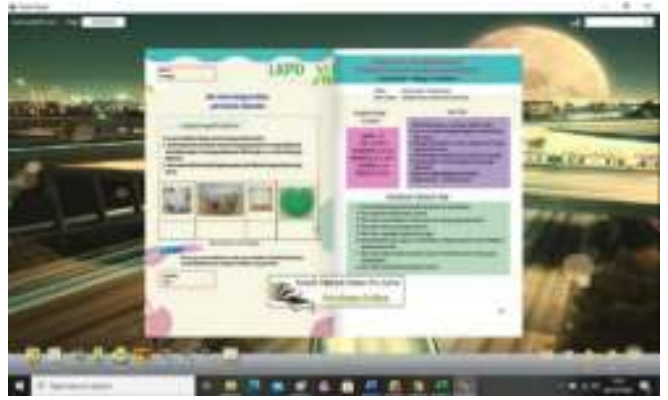

\section{Gambar 8. Desain LKPD dan RPPM}

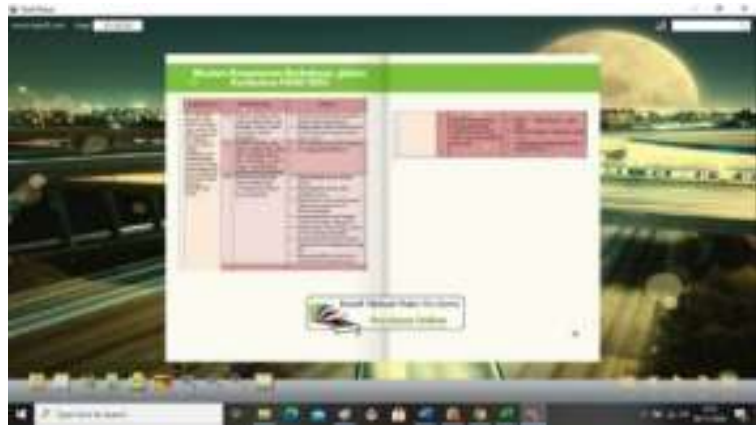

Gambar 10. Materi kesantunan berbahasa anak usia dini

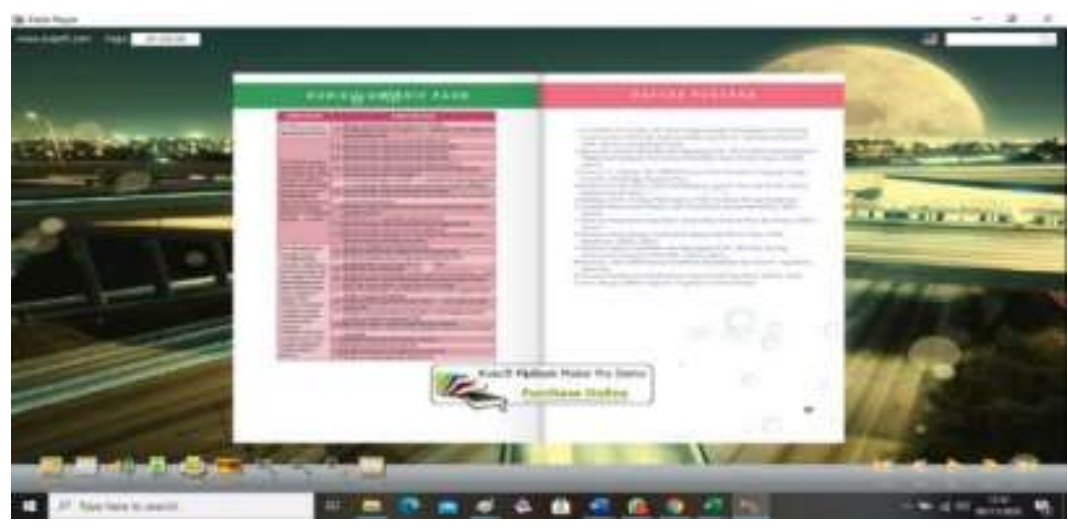

Gambar 11. Kurikulum 2013 PAUD dan daftar Pustaka

Setelah dilakukan pengembangan, selanjutnya e-module divalidasi oleh validator ahli yaitu validator materi dan validator media. Berdasarkan saran dari validator, peneliti melakukan revisi, selanjtnya melakukan uji coba terbatas. 


\section{Implementation (Implementasi)}

Implementasi merupakan tahapan menggunakan e-module. Setelah dilakukan uji coba terbatas dan dinyatakan layak oleh validator maka selanjutnya e-module di implementasikan pada anak dikelompok besar. Namun karena kondisi pandemi dan kebijakan pemerintah kabupaten Dharmasraya, Sumatera Barat yang memberlakukan kegiatan pembelajaran tatap muka terbatas sehingga pada tahap implementasi ini hanya melibatkan 15 orang anak TK Insan Kamil Kabupaten Dharmasraya yang terdiri dari 8 orang anak dari kelas B1 dan 7 orang anak dari kelas B2 serta dua orang guru TK Insan Kamil. Sebelum menggunakan e-module tematik berbasis kesantunan berbahasa peneliti dibantu oleh guru melalukan penilaian terhadap penanaman kesantunan berbahasa pada anak (pre-test). Hal ini dilakukan untuk mengetahui perubahan sikap kesantunan berbahasa anak dengan menggunakan e-module. Selanjutnya guru menggunakan e-module tematik berbasis kesantunan berbahasa sebagai bahan ajar dalam kegiatan pembelajaran. dan melakukan penilaian terhadap e-module dalam hal ini adalah uji praktikalitas.

Uji praktikalitas merupakan uji tingkat keterpakaian atau kemudahan e-module tematik berbasis kesantunan berbahasa untuk digunakan oleh guru taman kanak-kanak. Aspek yang diukur adalah aspek kemudahan dan waktu dalam penggunakan e-module. Uji praktikalitas e-module ini adalah sebagai berikut: pertama, guru TK Insan Kamil. Dengan memberikan angket praktikalitas kepada guru setelah menggunakan e-module tematik sebagai bahan ajar dalam pembelajaran; kedua, uji praktikalitas dilakukan dengan mengadakan kelompok diskusi terfokus (Focus Groub Discussion atau FGD).

Metode FGD merupakan metode yang memiliki tingkat high face validity dan secara umum berorientasi pada prosedur penelitian. Satu kelompok diskusi FGD dapat terdiri dari dari 6 sampai 10 individu (Tipping \& Tennenbaum, 1993). Kegiatan FGD dilakukan secara virtual yang diikuti oleh 11 orang guru taman Kanak-kanak sebagamana pada tabel 2. Setelah melakukan diskusi tentang e-module tematik dan menggunakan e-module guru mengisi angket praktikalitas.

Selain uji praktikalitas juga dilakukan uji efektivitas. Uji efektivitas merupakan tahapan penilaian terhadap efektivitas e-module tematik berbasis kesantunan berbahasa dalam penanaman kesantunan berbahasa anak usia 5-6 tahun. Pengamatan dilakukan oleh peneliti melalui pengamatan saat proses pembelajaran menggunakan e-module tematik. Dalam hal ini peneliti dibantu oleh guru dalam memantau peningkatan kesantunan berbahasa anak.

Tabel 2. Peserta Kelompok Diskusi Terfokus E-module

\begin{tabular}{clllc}
\hline No & \multicolumn{1}{c}{ Nama } & \multicolumn{1}{c}{ Sekolah } & \multicolumn{1}{c}{ Kab/kota } & Keterangan \\
\hline 1 & Yossi Srianita, M.Pd & TK Babussalam & Jakarta Pusat & Fasilitator \\
2 & Deli Rozalina, S.Pd & PAUD Mande & Solok & Notulen \\
3 & Afrizawati, S.Pd & TK Nurul Huda & Sawahlunto & Peserta \\
4 & Nurhasna, S.Pd & TK. Pertiwi 4 & Sawahlunto & Peserta \\
5 & Ardawti, S.Pd & TK Pembina & Sawahlunto & Peserta \\
6 & Yelni, S.Ag & TK Al-Azhar 32 & Kota Padang & Peserta \\
7 & Meida Susanti, S.Pd & TK Latihan SPG & Kota Padang & Peserta \\
8 & Mahdaleni, S.Pd & TK Al-Azhar & Pasaman Barat & Peserta \\
9 & Deni Rahmalia, S.Pd & PAUD Terpadu As-Salam & Bukittinggi & Peserta \\
10. & Misrayeti, S.Pd & TK Islam Raudatul Jannah & Payakumbuh & Peserta \\
11. & Jumaini, M.Pd & PAUD Terpadu Bakti 36 & Kepulauan Mentawai & Peserta \\
\hline
\end{tabular}

Tabel 3. Hasil Uji Praktikalitas Media

\begin{tabular}{lcccccc}
\hline \multicolumn{1}{c}{ Aspek } & \multicolumn{2}{c}{ Nilai } & Jumlah & item & Average & Kategori \\
& V1 & V2 & & & & \\
\hline Kemudahan dalam Penggunaan & 39 & 37 & 76 & 8 & 9,5 & Sangat Praktis \\
Waktu yang digunakan & 9 & 9 & 18 & 2 & 9,0 & Sangat Praktis \\
Total & 48 & 46 & 94 & 10 & 9,4 & Sangat Praktis \\
\hline
\end{tabular}




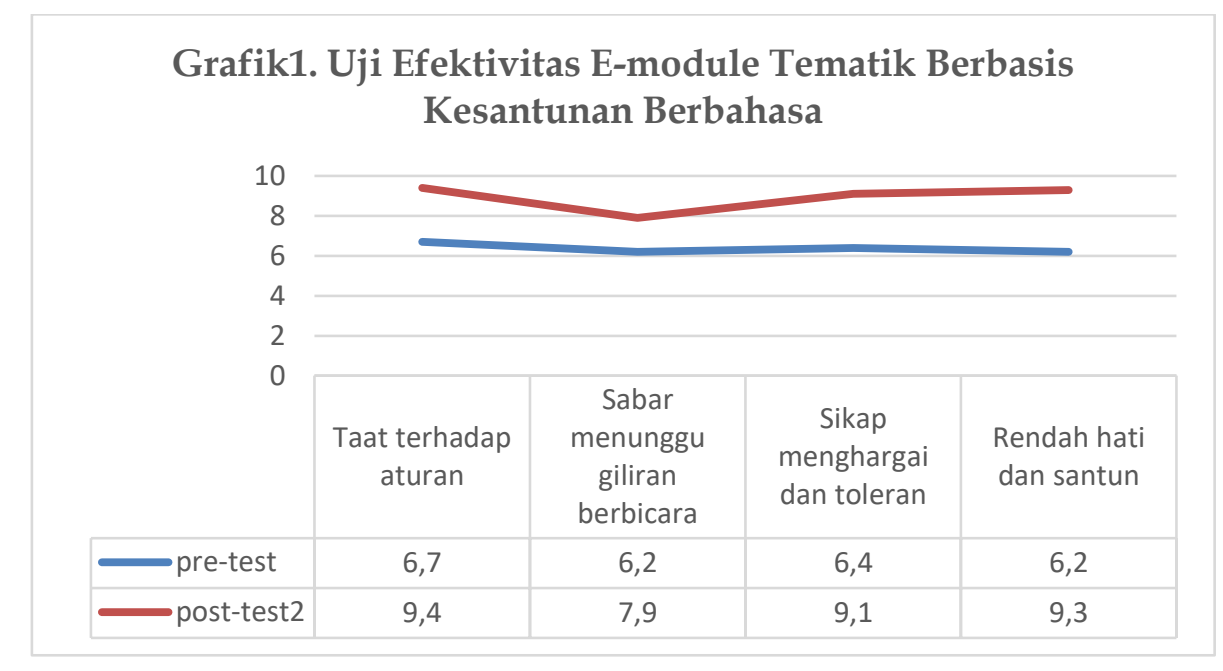

Grafik 1 Hasil Uji Efektivitas Media

\section{Evaluation (Evaluasi)}

Evaluasi dilakukan berdasarkan lembar penilaian dari beberapa ahli yaitu ahli materi kesantunan berbahasa anak usia dini, ahli materi tematik pendidikan anak usia dini dan ahli media e-module tematika berbasis kesantunan berbahasa. Selain dari lembaran penilaian dari ahli, evaluasi juga berbasarkan angket respon guru taman kanak-kanak. Adapun revisi terhadap e-module adalah pada beberapa kalimat masih terlalu Panjang untuk anak usia dini, emncantumkan sumber gambar yang dimuat pada e-module dan selanjutnya adalah pada cover emodule yaitu mengurangi tulisan pada cover karena dianggap terlalu ramai sehingga menjadi kurang menarik. Setelah melakukan revisi e-module selanjutnya dilakukan uji praktikalitas dan efektivitas.

Dari hasil penilaian ahli konten kesantunan berbahasa anak usia dini memiliki validitas item memadai valid. Selanjutnya hasil penilaian uji praktikalitas e-module terhadap aspek kemudahan dalam penggunaan dan waktu yang digunakan menyimpulkan bahwa emodule tematik berbasis kesantunan berbahasa anak usia dini di taman kanak-kanak dinyatakan praktis. Sedangkan hasil presentasi efektifitas yang dilakukan melalui pengamatan terhadap anak saat proses pembelajaran terhadap penanaman karakter kesantunan berbahasa berada pada kategori efektif.

Desain modul tematik berbasis kesantunan berbahasa anak usia dini didesain menggunakan aplikasi canva, sehingga terlihat menarik dan dapat meningkatkan minat dan motivasi belajar anak. Selanjutnya modul dirubah menjadi modul elektronik atau e-module menggunakan sofware kvisoft flipbookmaker. Aplikasi ini memiliki banyak fitur pendukung antara lain mampu menghasilkan media interaktif, media pembelajaran, bahan ajar dan mampu membuat animasi sehingga menjadikan e-module pembelajaran lebih menarik dan kontekstual. Selain itu, dapat membantu menumbuhkan keinginan belajar kepada peserta didik untuk memperkenalkan nilai-nilai kesantunan berbahasa. E-Module ini merupakan salah satu inovasi baru dalam dunia pendidikan. Karena, selama ini belum ada dikembangakan e-module atau bahan ajar digital yang berbasis kesantunan berbahasa. Pengembangan e-module tematik ini menggunakan model ADDIE dengan 5 tahapan yaitu Analys, Design, Development, Implementation dan Evaluation.

Tahap awal dalam pengembangan e-module ini adalah melakukan analisis kebutuhan. Anaisis kebutuhan merupakan kegiatan menganalisis silabus atau kurikulum untuk memperoleh informasi modul yang dibutuhkan peserta didik dalam mempelajari kompetensi yang telah diprogramkan karena kurikulum sebagai kerangka terorganisir yang menggambarkan isi, proses pembelajaran untuk membantu anak-anak mencapai tujuan apa yang guru lakukan untuk membantu anak-anak mencapai tujuan, dan konteks di mana pengajaran dan pembelajaran terjadi (SURYANA, 2017) Setelah melakukan analisis, langkah 
selanjutnya adalah membuat desain. Tahap desain berkaitan dengan desain dalam merumuskan tujuan pembelajaran, instrumen penilaian, latihan, konten dan analisis materi pelajaran, perencanaan pembelajaran dan pemilihan media (Tung \& Alissa, 2021).

Sebelum mengembangkan modul pembelajaran peneliti perlu mengetahui lebih dulu beberapa karakteristik modul yang baik. Terdapat beberapa kriteria utama modul pembelajaran yang baik yaitu tujuan pembelajaran yang tepat; pengetahuan disusun sedemikian rupa mencakup kemampuan intelektual, kognitif, invormasi verbal, sikap dan keterampilan psikomotor; memuat sistem penilaian berdasarkan penguasaan; memuat semua unsur pembelajaran dan tugas atau latihan dengan memperhatikan perbedaan individu peserta didik, dan mengarah pada suatu tujuan belajar tuntas (Yaumi, 2018). Dengan memperhatikan hal-hal tersebut peneliti mulai menyusun kerangka e-module. Penulisan emodule dibuat sesuai dengan RPP.

Langkah selanjutnya adalah mendeskripsikan kerangka e-module tematik, menyusun materi pembelajaran sesuai dengan tema dan konten yang akan dikembangkan. Setelah materi selesai disusun dalam bentuk modul berdasarkan tema dan sub tema yang dikembangkan lalu didesain menggunakan aplikasi canva. Modul ini kemudian diproses menjadi modul elektronik atau e-module menggunakan aplikasi kvisoft flipbook maker. Peneliti menggunakan aplikasi kvisoft flipbook maker ini karena aplikasinya tidak hanya dapat menkonversi modul ke dalam bentuk e-module namun juga dapat memuat media pembelajaran seperti video, audio, animasi gerak yang dapat menarik minat anak belajar dengan menyenangkan (Wibowo \& Pratiwi, 2018) karena anak lebih tertarik dan senang belajar jika menggunakan media pembelajaran yang bersifat interaktif (Mahyuddin et al., 2018)

Selanjutnya dirancang buku saku panduan penggunaan e-module tematik berbasis kesantunan berbahasa untuk memudahkan guru dalam mengoperasikan e-module. Untuk menghasilkan e-module yang layak maka dilakukan serangkaian validasi ahli materi, validasi ahli media, uji praktikalitas dan uji efektivitas

\section{SIMPULAN}

Hasil penelitian menunjukkan bahwa (1) desain e-module tematik berbasis kesantunan berbahasa anak usia dini di taman kanak-kanak dinyatakan memiliki item yang valid dan hasil kelayakan materi dan media emodule dinyatakan layak digunakan; (2) e-module tematik berbasis kesantunan berbahasa anak usia dini dinyatakan praktis sebagai bahan ajar di taman kanak-kanak; (3) e-module tematik berbasis kesantunan berbahasa anak usia dini dinyatakan efektif sebagai bahan ajar di taman kanak-kanak.

\section{UCAPAN TERIMA KASIH}

Penulis mengucapkan terima kasih kepada validator ahli yang telah bersedia memvalidasi e-modelu ini sehigga layak untuk digunakan sebagai bahan ajar di taman kanakkanak. Peneliti juga mengucapkan terima kasih kepada semua guru taman kanak-kanak dan guru PAUD terpadu yang bersedia menjadi responden pada uji praktikalitas dan sangat membantu kelancaran penelitian ini.

\section{DAFTAR PUSTAKA}

Al-Tabany, T. I. B. (2013). Desain Pengembangan Pembelajaran Tematik Bagi Anak Usia Dini TK/RA \& Anak Usia Kelas Awal SD/MI: Implementasi Kurikulum 2013. In Kencana Prenada Media Group PSIKOLOGI.

Branch, R. M. (2019). Robert Maribe Branch - Instructional Design (The ADDIE Approach). In Journal of Chemical Information and Modeling.

Brown, P., \& Levinson, S. C. (1988). Politeness: Some Universals in Language Usage. Interactional Sociolinguistic, 4. https:// doi.org/10.1017/CBO9780511813085 
Burdelski, M. (2010). Socializing politeness routines: Action, other-orientation, and embodiment in a Japanese preschool. Journal of Pragmatics, 42(6), 1606-1621. https:// doi.org/10.1016/j.pragma.2009.11.007

Ferdianto, F., Setiyani, \& Nurulfatwa, D. (2019). 3D page flip professional: Enhance of representation mathematical ability on linear equation in one variable. Journal of Physics: Conference Series, 1188(1). https://doi.org/10.1088/1742$\underline{6596 / 1188 / 1 / 012043}$

Kurniadi, F., Hilaliyah, H., \& Hapsari, S. N. (2017). Membangun Karakter Peserta Didik Melalui Kesantunan Berbahasa. AKSIOLOGIYA: Jurnal Pengabdian Kepada Masyarakat, 2(1). https:// doi.org/10.30651/aks.v2i1.1023

Larson, L. C., \& Miller, T. N. (2011). 21st Century Skills: Prepare Students for the Future. Kappa Delta Pi Record, 47(3), 121-123. https:// doi.org/10.1080/00228958.2011.10516575

Mahyuddin, M.Pd, D. N., \& Rozimela, Ph, d, P. D. Y. (2019). Polite Language Learning Model through Interactive Learning $\mathrm{CDs}$ at Bukittinggi Kindergarten. https:// doi.org/10.2991/icoie-18.2019.133

Mahyuddin, N., Rozimela, Y., \& Yaswinda. (2018). Model Pembelajaran Berbahasa Santun Melalui CD Pembelajaran Interaktif di Taman Kanak-Kanak Aisyiyah Pariaman. Yaa Bunayya: Jurnal Pendidikan Anak Usia Dini, 2(II), 49-54.

Mahyurianti, \& Mahyuddin, N. (2020). The Application of Audio Visual Media Based on Minangkabau Folklore to Develop Children's Speaking Ability in Kindergarten Kartika 1-7 Padang. https:// doi.org/10.2991/assehr.k.200715.026

Pengelola Web Kemdikbud. (2020). Kemendikbud Terbitkan Pedoman Penyelenggaraan $\begin{array}{lllll}\text { Belajar dari } & \text { Rumah. Jakarta, } 2820 .\end{array}$ https:// www.kemdikbud.go.id/main/blog/2020/05/kemendikbud-terbitkanpedoman-penyelenggaraan-belajar-dari-rumah

Ramadhan, S., \& Linda, R. (2020). Pengembangan E-Module Interaktif Chemistry Magazine Berbasis Kvisoft Flipbook Maker Pada Materi Laju Reaksi. Jurnal Zarah, 8(1), 7-13.

Rizki Tiara, D., \& Pratiwi, E. (2020). Mengukur Kesiapan Guru Sebagai Dasar Pembelajaran Daring Di Lembaga PAUD. Jurnal Golden Age, 4(02), 362-368. https:// doi.org/10.29408/jga.v4i02.2624

Situmorang, M., Yustina, Y., \& Syafii, W. (2020). E-Module Development using Kvisoft Flipbook Maker through the Problem Based Learning Model to Increase Learning Motivation. Journal of Educational Sciences, $4(4), \quad 834$. https://doi.org/10.31258/jes.4.4.p.834-848

Sofyan, H., Anggereini, E., Muazzomi, N., \& Larasati, N. (2020). Developing an electronic module of local wisdom based on the area learning model at Kindergarten Jambi city. International Journal of Innovation, Creativity and Change, 11(2), 216-231.

Suhendro, E. (2020). Strategi Pembelajaran Pendidikan Anak Usia Dini di Masa Pandemi Covid-19. Jurnal Golden Age, 5(3), 133-140. https:// doi.org/10.14421/iga.2020.53-05

Supriatna, D., \& Mulyadi, M. (2009). Konsep dasar desain pembelajaran. In Bahan ajar untuk Diklat E-Training PPPPTK TK dan PLB. Pusat Pengembangan dan Pemberdayaan Pendidik dan Tenaga Kependidikan Taman Kanak Kanak dan Pendidikan Luar Biasa.

Suryana, D. (2016). Stimulasi \& aspek Perkembangan Anak Usia Dini. In Kencana. Kencana. https:/ / books.google.co.id/books?hl=en\&lr=\&id=qQRBDwAAQBAJ\&oi=fnd\&pg=P A245\&dq=sejarah+pendidikan+anak+usia+dini+\&ots=LzpgmobKlv\&sig=OnHqhjOd sYYP0tRVyo3jmCa7pS8\&redir_esc $=\mathrm{y} \# \mathrm{v}=$ onepage $\& \mathrm{q}=$ sejarah pendidikan anak usia dini\&f $=$ false

Suryana, D. (2017). Pembelajaran Tematik Terpadu Berbasis Pendekatan Saintifik Di Taman Kanak-Kanak. JPUD - Jurnal Pendidikan Usia Dini, 11(1), 67-82. https:// doi.org/10.21009/JPUD.111.05 
Tipping, J., \& Tennenbaum, J. (1993). The use of focus groups as a tool for CME program evaluation. Journal of Continuing Education in the Health Professions, 13(1), 117-122. https://doi.org/10.1002/chp.4750130106

Triyono, M. B. (2015). The Indicators of Instructional Design for E- learning in Indonesian Vocational High Schools. Procedia - Social and Behavioral Sciences, 204, 54-61. https://doi.org/10.1016/j.sbspro.2015.08.109

Tung, K. Y., \& Alissa, A. (2021). Flipperentiated Learning in Biology Class to Improve Cognitive Learning Outcomes, Problem-Solving Skill, and Motivation. International Journal of Education and Literacy Studies, 9(1), 183. https://doi.org/10.7575/aiac.ijels.v.9n.1p.183

Wibowo, E., \& Pratiwi, D. D. (2018). Pengembangan Bahan Ajar Menggunakan Aplikasi Kvisoft Flipbook Maker Materi Himpunan. Desimal: Jurnal Matematika, 1(2), 147. https://doi.org/10.24042/djm.v1i2.2279

Yaumi, M. (2018). Media dan Teknologi Pembelajaran - Dr. Muhammad Yaumi, - Google Buku. In Prenata Media Group. https:/ / books.google.co.id/books?id=2uZeDwAAQBAJ\&printsec=frontcover\&dq=p engertian+media+pembelajaran\&hl=id\&sa=X\&ved=2ahUKEwiZ4c7fhZLvAhXUSH0 KHcQ4BQMQ6AEwAnoECAQQAg\#v=onepage\&q=pengertian media pembelajaran\&f=false\%0Ahttps:/ / books.google.co.id/books?id=2uZe

Yuliastri, N. A., \& Ramdhani, S. (2018). Pengembangan Pembelajaran Tematik Integratif Untuk Meningkatkan Nilai Karakter Anak Usia Dini. Jurnal Golden Age, 2(01), 44. https://doi.org/10.29408/goldenage.v2i01.898

Zaharah, Z., \& Susilowati, A. (2020). Meningkatkan Motivasi Belajar Peserta Didik Dengan Menggunakan Media Modul Elektronik Di Era Revolusi Industri 4.0. BIODIK, 6(2), 3952. https:// doi.org/10.22437/bio.v6i2.8950

Zhang, L., \& Yan, R. (2012). Impact of Immersion Teaching on English Sociopragmatic Awareness of Chinese Kindergarten Children: A Polite Study. International Education, 41(2), 33-45. 